\title{
CAPUT DIDI.
}

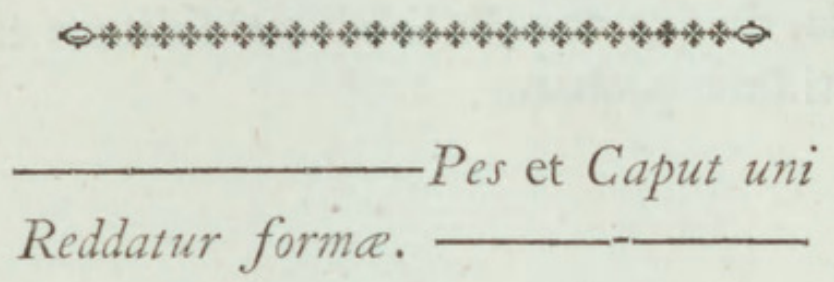

Cum ego nuper verum et genuinum Didi pedem in Mufeo Britannico detectum accurate depingi curaverim, gratulor fane mihi quod jam oblata fit occafio reliquias pretiofiores lectoribus meis apponendi; roftrum nempe, cum fronte feu parte capitis ei adhuc adhærente. In hoc fingularis iftius avis veftigium faufte admodum incidi in Mufeo Afhmoleano apud Oxonienfes; in quo fatis notum eft contineri quicquid rarum collegerat celeberrimus Tradefcantius, qui id omne domino Eliæ Afhmole legavit, a quo poftea Academix donatum eft. In defcriptione Didi qui in tabula centefima vicefima et tertia hujus operis cernitur, Willoughbeii teftimonio ufus fum, qui exuvias avis in Mufeo Tradefcantiano fe vidiffe affirmaverat. Roftrum igitur de quo loquimur eft ipfiffimum fpecimen a Willoughbeio Raioque vifum; quod fideliter repræfentavimus, quale hodie confpicitur, id injuriarum paffum quas afferre folet annorum fpatium majus quam centum et quinquaginta. Notandum porro eft pedem quoque Didi, vetuftate exefum et mutilatum, in eodem Mufeo affervari, plene et perfecte congruentem cum illo quem fuppeditavit Mufeum 
Britannicum, quemque in hoc Naturæ Vivario non ita pridem defcripfimus. Vera igitur iftius avis exiftentia, de qua nonnihil dubitari folitum eft, tandem certifime probatur. 



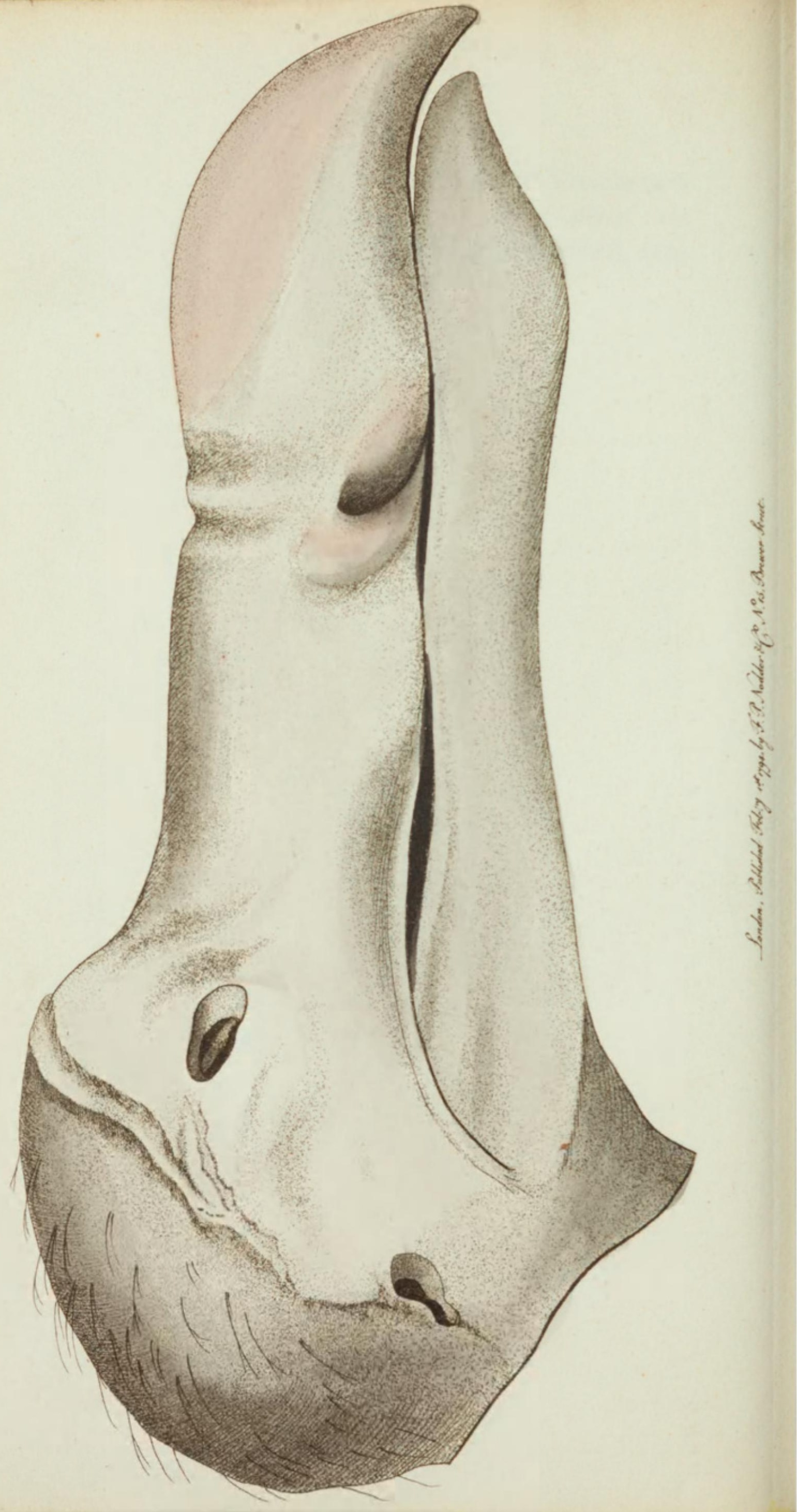




\section{HEAD OF THE DODO.}

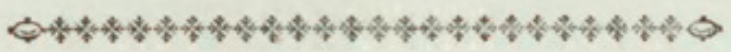

Having fome months ago afcertained in the Britifh Mufeum the leg of a Dodo, and given in a preceding number an exact reprefentation of it, I have now the pleafure of prefenting my readers with a ftill more fatisfactory relique of that fingular bird, viz. the beak, with the fore-part of the head ftill adhering to it. This I was fo fortunate as to difcover very lately in the Afhmolean Mufeum at Oxford, in which, as is well known, is contained the collection of the famous John Tradefcant, by whom it was bequeathed to Mr. Elias Afhmole, who prefented it to the univerfity: In the defcription of the Dodo at plate 123 of the prefent work, I have obferved that we have the teftimony of Willoughby for the exiftence of the exuviæ of the Dodo in the Tradefcantian Mufeum. The beak therefore here figured is that belonging to the fpecimen feen by Willoughby and Ray. It is moft faithfully reprefented as it now appears, having fuffered fome injuries from the lapfe of more than a century and half. I fhould not omit to obferve that a leg of the Dodo (tho' in an extremely bad ftate of prefervation), exifts in the fame collection; in fize and every other particular agreeing with that belonging to the Britifh Mufeum. The exiftence therefore of the Dodo, which has lately been confidered as fomewhat problematical, is now in the fulleft and moft fatisfactory manner afcertained. 


\section{$2 \mathrm{BHL}$ Biodiversity Heritage Library}

Shaw, George. 1794. "The Head of the Dodo, Caput didi [PI. 166]." The Naturalist's Miscellany 5(LV), https://doi.org/10.5962/p.310745.

View This Item Online: https://www.biodiversitylibrary.org/item/276340

DOI: https://doi.org/10.5962/p.310745

Permalink: https://www.biodiversitylibrary.org/partpdf/310745

\section{Holding Institution}

Museums Victoria

\section{Sponsored by}

Atlas of Living Australia

\section{Copyright \& Reuse}

Copyright Status: Public domain. The BHL considers that this work is no longer under copyright protection.

This document was created from content at the Biodiversity Heritage Library, the world's largest open access digital library for biodiversity literature and archives. Visit BHL at https://www.biodiversitylibrary.org. 